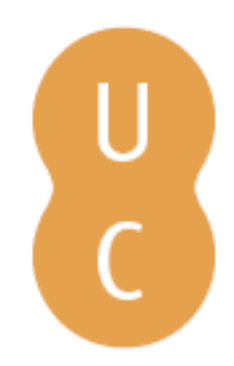

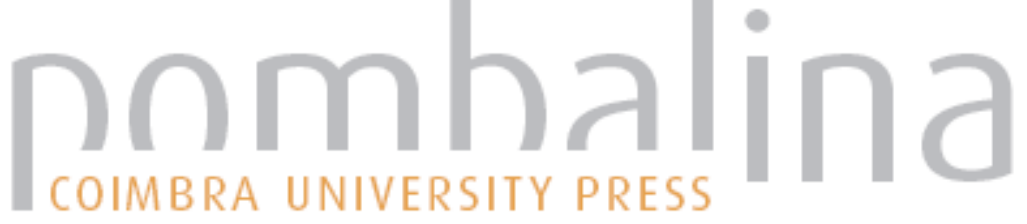

\section{The Great Advances in Mathematics in the Context of Alexandrian Culture}

\author{
Autor(es): $\quad$ Gamas, Carlos Alberto Duarte \\ Edições Afrontamento; CITCEM - Centro de Investigação \\ Publicado por: Transdisciplinar "Cultura, Espaço e Memória»; Centro de Estudos \\ Clássicos e Humanísticos; Alexandria University; Imprensa da \\ Universidade de Coimbra \\ URL $\quad$ URIstente: $\quad$ URttp://hdl.handle.net/10316.2/36188 \\ DOI: $\quad$ DOI:http://dx.doi.org/10.14195/978-989-26-0966-9_22 \\ Accessed : $\quad$ 26-Apr-2023 13:09:00
}

A navegação consulta e descarregamento dos títulos inseridos nas Bibliotecas Digitais UC Digitalis, UC Pombalina e UC Impactum, pressupõem a aceitação plena e sem reservas dos Termos e Condições de Uso destas Bibliotecas Digitais, disponíveis em https://digitalis.uc.pt/pt-pt/termos.

Conforme exposto nos referidos Termos e Condições de Uso, o descarregamento de títulos de acesso restrito requer uma licença válida de autorização devendo o utilizador aceder ao(s) documento(s) a partir de um endereço de IP da instituição detentora da supramencionada licença.

Ao utilizador é apenas permitido o descarregamento para uso pessoal, pelo que o emprego do(s) título(s) descarregado(s) para outro fim, designadamente comercial, carece de autorização do respetivo autor ou editor da obra.

Na medida em que todas as obras da UC Digitalis se encontram protegidas pelo Código do Direito de Autor e Direitos Conexos e demais legislação aplicável, toda a cópia, parcial ou total, deste documento, nos casos em que é legalmente admitida, deverá conter ou fazer-se acompanhar por este aviso.

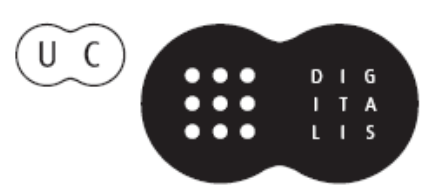




\title{
THE GREAT ADVANCES IN MATHEMATICS IN THE CONTEXT OF ALEXANDRIAN CULTURE
}

\section{CARLOS ALBERTO DUARTE GAMAS}

University of Coimbra.

\begin{abstract}
This chapter aims to provide an overview of scientific activity in the area of Mathematics and other sciences connected to it (Geography, Astronomy, Mechanics), in Alexandria and also in the broader context of Alexandrian culture, from its golden age to its decline.
\end{abstract}

The fact that Mathematics thrived in Greek culture, in the Classical period and in the Hellenistic, was always linked to the mobility of the cultured minds of those times. In Greece, throughout the Classical period, the Academy, founded by Plato (ca. 387-385 B.C.), played an important role in this context, for it became a focal centre of research for the most remarkable philosophers and scientists, who came from Asia Minor or the Eastern Mediterranean islands, influenced by the ancient Mathematics of the Near East, or from the western area of the Mediterranean, Sicily, with different education acquired in their countries of origin ${ }^{1}$. At the Academy scholars discussed different advances and methods to approach mathematical issues ${ }^{2}$. Mathematika at the time included Arithmetics, Geometry, Astronomy and Harmonics. Aristotle attended the Academy and, soon after arriving in Athens again, founded in 335 B.C. the Lyceum. His methodological principles veer from

\footnotetext{
${ }^{1}$ It is not my aim to focus on and discuss the major lines of thought of this tradition, such as the complex Pythagorical area. On this subject see CORNELLI, 2011, and the author's bibliographical basis.

${ }^{2}$ On the mathematical activity at the Academy see, in particular, FOWLER, 1990.
} 
what Lasserre (1964) calls the "ontological mathematics» ${ }^{3}$ of Plato's circle. For Aristotle the basic methodology is observation and experimentalism, in an effort to apply mathematical knowledge (like mechanics) to Mathematics itself.

Mathematician Hippocrates, who came from the island of Chios to the Academy, in the 5th century B.C., was the first author of a compilation of Elements, where there seems to have been early research on the resolution of the duplication of the cube (known in the Antiquity as the problem of Delos ${ }^{4}$ ) and on the circle quadrature. By the time of Plato's death, one of his disciples, Theudius of Magnesia, wrote a new compilation of Elements. There was also a mathematician of unknown origin, Leon, who attended the Academy between 365-360 B.C. and wrote a volume called Elements. Euclid's work therefore follows an established tradition and combines a collection of organized mathematical knowledge with the results of his own mathematical activity.

Another name that determined the future of Alexandrian mathematicians' research was Eudoxus of Cnidus, who came to Athens and remained there for some time, establishing a scientific relationship with Plato. He brought some disciples to the Academy from the school he founded in Cyzicus, to where he later returned.

This master-disciple relationship is also a feature of the circle of the Lyceum or Peripatos. It is in fact one of Aristotle's followers, Demetrius of Phaleron, who will come to live in Alexandria, in Ptolemy I Soter's court ${ }^{5}$. He seems to have been the one to encourage the king to create the Library, in the space adjacent to the newly-founded Museum ${ }^{6}$. Awareness of the rich cultural and scientific Greek heritage creates the need to archive, collect, compile, whether in arts and humanities or sciences.

Studies in Mathematics in Alexandria combine two tendencies: emphasizing on the recovery and development of research traditions, and bringing together mathematical research and its practical application. Thus most part of the Alexandrian mathematicians or, in more general terms, the mathematicians of Hellenistic culture, are simultaneously geographers, mechanics experts or astronomers. These studies will flourish during approximately half a millenium.

Later on Aristarchus of Samos (ca. 310-230 B.C.), influenced by the ancient teachings of Pythagorean Philolaus of Tarentum, raised strong indignation and accusations of impiety among the Stoics when he claimed that the earth moves around the sun, which is fixed. However, there is no written account of this perception: on the contrary, his treatise On the

\footnotetext{
${ }^{3}$ Pp. 22-23.

${ }^{4}$ On the origin and nature of this problem, see EVES, 1990: 111-112.

${ }^{5}$ The first Ptolemy ruled from 305 to 285 B.C.

${ }^{6}$ Space of culture and cult to the Muses. The tradition of associating cult and culture can be found in the Academy, where there seems to have been also an area for the cult to the Muses. Later in Alexandria another smaller library was founded, near the temple known as Serapeum, devoted to Sarapis.
} 
sizes and distances of the Sun and the Moon, likely written prior to his discovery, assumes a geocentric universe ${ }^{7}$. In it Aristarchus calculated the dimensions of the Sun, the Earth and the Moon, as well as the distance between the three celestial bodies, even though without absolute accuracy, by adequate geometric processes. He calculated the length of the sides of the triangle formed by the three bodies when the Moon is in quadrature, considering that the latter is at the vertex of a right triangle and that the other two vertices correspond to the position of the earth and the sun. Be as it may, this assumes trigonometric calculi. He identified planets of the solar system and observed the solstice of 280 B.C. He attended the Museum and the Library of Alexandria, and due to his prestige the king appointed him as tutor to his son.

But the great pioneer of studies in Mathematics in Alexandria was Euclid, whose work will remain current until Modernity and who is known to have been active during the reign of Ptolemy I, who ascended the throne of Egypt in 330 B.C., two years after Alexander's death. According to tradition, he was invited by Demetrius of Phaleron, after the foundation of the Museum, to create a school of Mathematics there and form disciples. He wrote several works, among which Data ${ }^{8}$, Phaenomena, Porisms (lost) ${ }^{9}$, Optics, Caloptics, Division of Figures (which survived through an Arabic version) and considerations about plans and sections of the cone, a subject which his most outstanding disciple Apollonius of Perge will continue to work on. But Euclid's most important work, which will make him one of the most famous mathematicians in Antiquity bearing repercussions until modernity, is Elements, in thirteen volumes (volumes XIV and XV are apocrypha).

Euclid's Elements are one of the most remarkable works, combining the compilation of extremely relevant mathematical knowledge inherited from Greek classical tradition, which had begun being recorded at least two centuries earlier as Elements, with new studies and advances arising from Euclid's mathematical research. Indeed, since Antiquity only the Bible and perhaps Homer were as disseminated as Euclid's Elements: the latter remained the core of mathematical teaching during more than two Millennia ${ }^{10}$. As highlighted by Dugac, based on excerpts of Euclid's Elements, «il parle une nouvelle langue mathématique» ${ }^{11}$. Elements were part of the 15th century incunabula, with two editions. Only in the 19th century, with Lobachevsky, Bolyai and Riemann, non-Euclidean geometries will come to light.

\footnotetext{
${ }^{7}$ MERZBACH-BOYER, 2011: 145.

${ }^{8}$ MERZBACH-BOYER, 2011: 92 on Data: «It seems to have been composed for use at the Museum of Alexandria., serving as a companion volume to the first six books of the Elements in much the way that a manual of tables supplements a textbook».

${ }^{9}$ "The loss of the Euclidean Porisms is particularly tantalizing. Pappus later reported that a porism is intermediate between a theorem, in which something is proposed for demonstration, and a problem, in which something is proposed for construction»: MERZBACH-BOYER, 2011: 91.

${ }^{10}$ The edition we use is the HEATH-DENSMORE, 2007, translation.
} 
The four first books deal with plan geometry, namely: book I deals with triangles, parallels and parallelograms and finishes with the famous Pythagoras Theorem; book II deals with the transformation of figures and geometrical shapes and presents the resolution of second degree algebraic equations; book III concerns the circle; book IV concerns regular polygons inscribed in or circumscribed about the circle; books V and VI expound the theory of proportions by Eudoxus of Cnidus. The central concept of the theory is the notion of «equal ratio». Book VI applies Eudoxus's theory of proportions to plane geometry. Euclid's theory on proportion provides the basis for a wide range of studies, in areas such as theory of equations, properties of fractions (although the concept of «fraction» is anachronic when applied to Euclid), the nature of «real number» system ${ }^{12}$. Books VII, VIII, VIII cover arithmetic and rational numbers, book VII begins with what would come to be known as the «Euclidean algorithm». Book X is the longest and complex. It contains one hundred and fifteen propositions. It deals with commensurable and incommensurable magnitudes ${ }^{13}$. Mieli $(1945)^{14}$ points out that the demonstration, in this volume, of the incommensurability of the diagonal of the square with reference to the side of the square allowed the Greeks of the Hellenistic Period to become acquainted with irrational magnitudes ${ }^{15}$. Books XI, XII, XIII contain propositions regarding geometry in space, frequently using the method that Eudoxus of Cnidus had already used before him - that of exhaustion. Book XIII demonstrates that there are five and only five regular solids that can be «inscribed» in or «circumscribed around» the sphere, by studying their construction. They are the cube, tetrahedron, octahedron, dodecahedron and icosahedron.

The versatility involved in the knowledge about these figures is eloquently exemplified by Erathostenes of Cyrene, considered by some scholars as «perhaps the greatest, and certainly the most comprehensive, of all the Alexandrian scholars ${ }^{16}$. For his versatile knowledge he is comparable to Aristotle ${ }^{17}$. He lived between 276-194 B.C. He cultivated what nowadays is called "humanities», theory of music, poetry, as well as mathematical sciences; the latter prevailed over the other activities - marking a new era beginning in the middle of the century. He studied in Cyrene, his city of birth, and was called to Alexandria by Ptolemy III Euergetes; he lived there until Ptolemy V's reign. He was chief librarian of the Library of

\footnotetext{
${ }^{11}$ DUGAC, 2003: 9.

${ }^{12}$ KATZ, 1993: 72.

${ }^{13}$ FOWLER, 1990: 19 makes an analysis of the significant interrelationship between Elements $V$ (theory of proportions) and Elements $X$, very pertinent for the full understanding of Euclid's commensurability/incommensurability. See also MERZBACH-BOYER, 2011: 105-106.

${ }^{14}$ MERZBACH-BOYER, 2011: 97.

${ }^{15}$ For a critical review of the analysis on the significance of the discovery of incommensurables see GONÇALVES-POSSANI, 2009. Drawing on Fowler's (p. 21) authoritative work, the authors argue and demonstrate that this discovery did not bring about a "crisis of fundaments of mathematics», contrary to what some researchers believe.

${ }^{16}$ MARLOWE, 1971: 70.

${ }^{17}$ PFEIFFER, 1968: 156.
} 
Alexandria. In addition to studies on the early Greek poets and on comedy, he focused on forms of calculus that led him to the measurement and form of the earth, concluding that it is spherical, and wrote, among other works, a treatise called On the Measurement of the Earth, and Geographica, in three books. Hence he is considered to be the father of mathematical Geography. He calculate the axis of the earth with remarkable precision and the distance between the Earth and the Sun. Application of his knowledge drove him to create instruments to measure longitudes and latitudes, determining distances (he was probably the author of the first geographical chart with indication of longitude and latitude). $\mathrm{He}$ worked out the 365-day calendar, adding a day to February every four years. He created instruments for the calculus of proportions: the mesolabium ${ }^{18}$, that enabled the resolution of the duplication of the cube (known as the "problem of Delos», a subject of study by the ancient Pythagoreans) and invented the "mathematical sieve», a table that allowed him to identify prime numbers up to a certain limit. Scarce fragments of his work survived.

Archimedes, «the greatest mathematical genius of Antiquity» ${ }^{19}$ comparable only to Galileum and Newton ${ }^{20}$, was born in Syracuse around 287 B.C., the son of an astronomer. In all likelihood he attended the Library and the Museum of Alexandria during his youth, where he became acquainted with scientists of that time. Although his biography is fairly detailed compared to other scientists', thanks to Plutarch's Life of Marcellus, there are no biographical data that support his presence in Alexandria ${ }^{21}$. But he was probably there, for the usage and existence in Egypt of one of his inventions, the hydraulical spiral screw, for land irrigation, is well documented (and it has been used until now); besides, some of his works are dedicated to Alexandrian scientists, like his Method, dedicated to Eratosthenes ${ }^{22}$, where he explained how he reached many of his conclusions, which he does not mention in any other work. Nevertheless it was in Syracuse that he established himself and developed his studies and applied them in military engineering, in defense of his city, until his death in 212 B.C., when the Romans besieged and conquered Syracuse. His use of mirrors calculated to reflect solar rays in order to set the Roman ships on fire, as well as a form of catapult based on the the principle of levers, is famous.

His invaluable and extensive research, from theory to practical application, covers several fields, making him one of the forefront mathematician-engineer in the history of science. Regarding his work in arithmetic and geometry, through the application of the process of the "quadrature of the circle», Archimedes inscribes in and circumscribes around the circle regular polygons (with up to 384 sides), until he finds an estimation of $\pi$, using a method that Eudoxus of Cnidos had already used in Plato's days: the method of exhaustion, which almost led him to the later infinitesimal calculus thanks to Archimedes's

\footnotetext{
${ }^{18}$ This is an instrument that made it possible to determine mean proportinals mechanically. See HODGKIN, 2005: 59, fig. 2.

${ }^{19}$ PFEIFFER, 1968: 155. Cf. LESKY, 1995: 828

${ }^{20}$ MIELI, 1945: 100.

${ }^{21}$ KATZ, 1993: 97.
} 
application. The calculus of $\pi$ was perpetuated by Apollonius of Perga and other mathematicians in Antiquity and the Middle Ages.

Archimedes also calculated the areas of solid figures. That is the subject of his two volume treatise On the Sphere and the Cylinder, where he demonstrates that if a sphere is inscribed in an equilateral cylinder the total area and the volume of the cylinder equals $3 / 2$ of the area and volume of the sphere. He thus implicitly resorted to integral calculus.

His studies on the spiral made him a precursor of differential calculus ${ }^{23}$.

Besides being credited by tradition for the Problem of the oxen, Archimedes was the author of a vast collection of works ${ }^{24}$ : On the Equilibrium of Planes (two books, where the first two principles of statics are established); Quadrature of the Parabola; Method (on mechanical proportions), dedicated to Eratosthenes; On the Sphere and the Cylinder (two books); On Spirals; On Conoids and Spheroids (designation of solids obtained by revolution - ellipsoid, paraboloid, hyperboloid); On Floating Bodies (two Books, where he postulated the principle of hydrostatics, among which the one that became known as the «Principle of Archimedes»); Measurement of a Circle; Arenarius, the main contribution of which is a preface with informations about Aristarchus of Samos's heliocentric theory. In fact, this is the only source of information on this theory. Arenarius deals with the expression of particularly large quantities. Its name derives from the calculation of sand grains required to fill the universe, based on the estimation of its dimension.

Of the manifold practical applications of Archimedes's and other scientists' works not enough is known, since their writings focused mainly on theoretical knowledge.

Two figures of reference among mathematicians-geometricians of Alexandria are Conon of Samos (ca. 280-ca.220 B.C) and Apollonius of Perge (ca. 262. B.C.-190 B.C.). The former, born in Samos, was attracted by the prestige and scientific activity of Alexandria. He would have likely become astronomer to Ptolemy III Euergetes's court. As an astronomer, he identified the constellation named «Coma Berenices», in honour of the queen consort ${ }^{25}$. In his Conics Apollonius mentions that Conon devoted himself to the study of Geometry, especially to the sections of the cone, and that the results of his research contributed to Apollonius's own research and work. This mathematician and astronomer, Euclid's most eminent disciple and possibly his successor at the Museum ${ }^{26}$, continued his master's research and wrote a treatise on the Sections of the Cone. He established geometrical terminology related to the result of his studies, such as «parabola», «ellipsis», «hyper-

\footnotetext{
${ }^{22}$ Archimedes is credited for the presentation of a problem, in the shape of a poem, in honour of Erastothenes: the «Problem of the Oxen", in the field of theory of numbers, concerning the number of oxen in the Helio's herd and mentioned as early as in Odyssey, XII.

${ }^{23}$ MIELI, 1945: cap. XI.

${ }^{24}$ Cf. MIELI, 1945: 102.

${ }^{25}$ According to MARLOWE, 1971: 74, Conon's astronomy is influenced later by eastern astrology.

${ }^{26}$ MARLOWE, 1971: 72.
} 
bole». He carried on the activity of calculus to solve the problem of the duplication of the cube.

There is scarce information about Zenodorus, an astronomer and geometrician who will have lived not long after Archimedes and attended the circles of scientists of contemporary Athens. He is mentioned herein for the mere fact that several of his theorems are cited in Theon of Alexandria's commentaries to Claudius Ptolemy.

Hipparchus of Bithynia, born in Nicaea (ca. 190 -120 B.C.), was considered by Gow as "one of the greatest geniuses of Antiquity» ${ }^{27}$, who drastically changed the state of the art of Astronomy. This relevant figure, whose biography is little known, developed his scientific activity as a geographer, mathematician and astronomer in Ptolemy VII's reign, spending his life between Alexandria and the island of Rhodes, where cultural life then was also thriving. There he set up an astronomical observatory. He identified 675 stars, determining their position by astronomical coordinates and even ellaborating a stellar catalogue. He discovered the precession of the equinoxes and the rotation of the axis of the Earth. Influenced by Babylonian knowledge, he is credited with the division of Earth in parallels spaced along the equator, and meridians drawn using the meridian of Rhodes, thus enabling the calculation and location of places. He rejected Aristarchus's heliocentric theory and instead adopted geocentrism. He invented instruments for measurement like the astrolabe. He created the armillary sphere as an instrument to help in his astronomical calculi.

The development of his studies in Astronomy and mathematical Geography has, of course, a deep interrelationship with the development of his research in the field of geometry; it is also connected with the practical application and theoretical improvement of geometry. Hipparchus is considered to be the founder of Trigonometry, even though the name appeared later and this trigonometry differs from modern one. Hipparchus's basic elements of trigonometry were based on the study of the relation between an arc and its chord $^{28}$. Hipparchus elaborated a trigonometric table.

His calculi will be continued and developed later on by Claudius Ptolemy.

In our era (ca. 100 A.D.) Menelaus of Alexandria continues the study of the relation between the arc and the chord, according to information left by commentator Theon in a six-volume treatise, Chords in a Circle. Greek and Arabic commentators mention others works of his in mathematics and astronomy, but the only one that survived was Sphaerica, in an Arabic version. In this treatise, inspired by Euclid's Elements, he adapts Euclidean methodology to calculate plane triangles to the calculus of spherical triangles. It may well be said that his aforementioned treatise is the first work on spherical trigonometry. In this context he authored a theorem named after him, the «Theorem of Menelaus»"

\footnotetext{
${ }^{27}$ Apud MARLOWE, 1971: 75.

${ }^{28}$ KATZ, 1993: 135.

${ }^{29}$ EVES, 1990: 176-177. Cf. KATZ, 1993: 143.
} 
In the beginning of our era another figure becomes significant: Nicomachus of Gerasa, born in modern-day Jordan, probably lived between around 60-120. Almost nothing is known about his biography. He embodies a new tendency: Neopythagoreanism, a school of thought that searches for the mystical properties of numbers, in deep harmony with music. The presence of Neopythagoreanism in his work leads us to believe that he lived and studied in Alexandria ${ }^{30}$. There are references to an Introduction to Arithmetic, a treatise on the theory of numbers, and to an Introduction to Harmonics. According to other sources, he will have written introductions to Geometry and Astronomy, hence covering the quadrivium of the ancient Platonic Academic. In his Introduction to Arithmetic, which remained an authoritative teaching cornerstone during a millenium, he presents the earliest-known Greek multiplication table. His work was translated into Latin by Apuleius and later by Boetius and was used until Renaissance.

Famous Claudius Ptolemy was of Greek-Roman origin. His biography is barely known. He was born at the end of the 1st century and lived until 168, approximately. He lived and developed his scientific activity in Alexandria, by the under Roman rule. His research, which he recorded, spans the fields of Mathematics, Astronomy and Geography, as well as Optics and Acoustics; his most influential work is called Syntaxis Mathematika or Mathematical Collection, in thirteen books. This work is referred to as «The Great Treatise» thanks to Ptolemy's fame and prestige in Antiquity and even among the recipients and transmitters of such scientific fields in the West: the Arabs ${ }^{31}$. So the latter continued to call Ptolemy's treatise «the greatest» - derived from the Greek superlative megistos, preceded by the Arabic article, hence Almagest. Its influence was felt throughout the centuries and not until Nicolaus Copernicus would heliocentrism be definitively adopted, recognizing the movement of the planets, the Earth included, of the solar system.

Ptolemy incorporated a great part of Hipparchus's astronomical and geographical theories and discoveries in his treatise, with the first book and part of the second one dedicated essentially to Mathematics. He developed and consolidated knowledge of plane and spherical trigonometry ${ }^{32}$. His «Theorem of Ptolemy» is worth quoting: «Given any quadrilateral inscribed in a circle, the product of the diagonals equals the sum of the products of the opposite sides» ${ }^{33}$.

Even though Ptolemy did not address the general notion of «function», he provides examples of tables where he establishes a functional relation between sets. The chord is expressed as a function of the arc, the declination of the sun as a function of longitude ${ }^{34}$.

Heron of Alexandria, a native of this city, lived during the 1st century (ca. 10-70). He

\footnotetext{
${ }^{30}$ KATZ, 1993: 158

${ }^{31}$ His work was translated into Arabic in 827.

${ }^{32}$ KATZ, 1993: 138-144.

${ }^{33}$ I quote Katz's formulation (1993) p. 138. Cf. MERZBACH-BOYER, 2011: 150-151.

${ }^{34}$ KATZ, 1993: 147.
} 
became known as a mathematician and engineer, a man devoted to experimentalism and the construction of machines, such a steam-powered machine. He taught at the Museum and devised «Heron's formula» for finding the area of a triangle from the length of its sides.

Diophantus, who lived to be eighty-four years old in his city of birth, Alexandria, during the 3rd century is considered to be the father of Algebra ${ }^{35}$. Little is known about his life. His major work, Arithmetika, was constituted by thirteen books, but only some of them survived into our days ( six in Greek, probably the ones commented by Hypatia ${ }^{36}$, and four in an Arabic translation). However, the teachings in those books influenced significantly later periods, until modernity. His work begins with a general introduction on polynoms and operations between them. He presents several problems of the first and second degree, as well as problems of indeterminate analysis.

Diophantus provided a major advancement in the solution of equations by introducing symbolism. Its worth noting that algebraic symbols begin by corresponding to abbreviations of numerical concepts. He later uses those symbols, associated to the symbol $\chi$ reciprocities ${ }^{3}$. For example $\Delta^{y x}$ represents $1 / \mathrm{x}^{2}$.

One of the last great mathematicians of Alexandria was Pappus. Nothing is known about his biography and no one even knows for sure the period he lived in. According to different informations, he may have developed his scientific activity in Alexandria either in the last quarter of the 3rd century or in the first half of the fourth century. He was not exactly an innovative spirit, but he fits the profile of the scientist who records and organizes the heritage of scientific information, when there were already signs of the decline of scientific activity in Alexandria. Therefore his was a role of major importance concerning mathematical information and theoretical Mechanics, which was left for posterity in an eightvolume work Mathematical Collection (Book I and part of Book II were lost). Citing Marlowe $(1971)^{38}$, «in this collection he has preserved the analytical method which the ancients employed in their researches, he made use of the centre of gravity, and has preserved the works of a number of otherwise unknown mathematicians». However, as noted by Katz $(1993)^{39}$, it is somewhat intriguing that Pappus does not cite Diophantus's strictly algebraic Arithmetika as an early example of analysis, given that the problems equated in Diophantus's work are solved based on Pappus's model.

At the twilight of this brilliant era of scientific activity lived Theon of Alexandria, of Greek-Egyptian origin. Hypatia's father lived in the 4th century and will have been the last major librarian of the great Library of Alexandria. Like Pappus, and in accordance with the

\footnotetext{
${ }^{35}$ The proto-notions came from Ancient Near East, the name is Arabic ('al.jabr'- usually rendered 'restoring'): HODGKIN, 2005: 110.

${ }^{36}$ MIELI, 1945: 251.

${ }^{37}$ The example is borrowed from KATZ, 1993: 163.

${ }^{38}$ KATZ, 1993: 74.

${ }^{39}$ KATZ, 1993: 176.
} 
period he lived in, Theon is essentially a commentator and editor. As such, he edited, with adaptations, and commented Euclid's Elements, as well as Ptolemy's Almagest, among other works. Mathematical knowledge is now cryistallized in the invaluable activity of perpetuating and commenting the outcome of previous mathematicansmathematicians' activity (some recorded in writing, others orally). There is no doubt that that activity increased with the awareness that such an heritage had to be preserved and to be passed along and commented to future commentators, even outside of Alexandria. Awareness of this fact proved to be correct.

With his activity and his daughter's fate a cycle comes to its end. Hypatia, following Plotinus's path, recaptures the tradition of the Academy - indeed, she was educated in Athens, which indicates that the influence and cultural prevalence of Alexandria had begun to fade away for some time. This woman devoted herself to Mathematics and Astronomy, as well as Philosophy. As we mentioned before, Hypatia perpetuates the tradition of commentating major mathematicians, such as Diophantus and Apollonius of Perge. Her scientific activity in Alexandria is complemented with teaching at the the Museum, no matter its location, after having been destroyed and rebuilt, contemporary to her life (ca. 350/370-415). Her teachings comprehended Mathematics and Philosophy. In fact, Hypatia turned out to be the major Alexandrian figure of Neoplatonism in her days.

In those days Christianity had gone from a persecuted religion to the official religion of the Empire, with Constantine. After the short period of paganism with Julian the Apostate, killed in 363, Christianity once again became the predominant religion, and a new order of logic, of a predominant religion persecuting heretics and pagans had emerged. Hypatia's prestige as a representative of the neoplatonist intellectual class turned her into a target of suspicions, someone to be taken down. She was thus murdered by a mob instigated by Patriarch Cyril's furious persecution. Hypatia's tragic end represents almost symbolically the definitive decline of science in Alexandria - in this particular instance, the end of the brilliant period of Mathematics. 